\title{
Sources and transport pathways of marine aerosol species into West Antarctica
}

\author{
S. KASPARI, D.A. DIXON, S.B. SNEED, M.J. HANDLEY \\ Climate Change Institute and Department of Earth Sciences, University of Maine, 303 Bryand Global Sciences Center, \\ Orono, ME 04469, USA \\ E-mail: susan.kaspari@maine.edu
}

\begin{abstract}
Sixteen high-resolution marine aerosol $\left(\mathrm{Na}^{+}, \mathrm{SO}_{4}{ }^{2-}\right)$ records from spatially distributed International Trans-Antarctic Scientific Expedition (ITASE) ice cores spanning the last $\sim 200$ years from the Pine Island-Thwaites and Ross drainage systems and the South Pole are used to examine sources (sea spray and frost flowers) and transport pathways of marine aerosols into West Antarctica. Factors contributing to the amount of marine aerosols transported inland include sea-ice extent, the presence of open-water features (polynyas, leads), wind strength and direction, and the strength and positioning of low-pressure systems. Analysis of $\mathrm{SO}_{4}{ }^{2-} / \mathrm{Na}^{+}$ratios indicates that frost flowers can contribute significantly $(40 \%)$ to the $\mathrm{Na}^{+}$budget of Antarctic ice cores. Higher $\mathrm{Na}^{+}$concentrations in the Ross drainage system may result from greater production of marine aerosols related to frost flowers in the Ross Sea region in association with greater sea-ice extent and larger open-water areas. Significant positive correlations of sea-ice extent and the $\mathrm{Na}^{+}$time series exist in some regions of West Antarctica. Higher wind speeds in winter and higher $\mathrm{Na}^{+}$concentrations when sea-level pressure is lower indicate that intensified atmospheric circulation enhances transport and production of marine aerosols.
\end{abstract}

\section{INTRODUCTION}

Antarctic climate is highly variable, with West Antarctica having the largest interannual climate variability (Cullather and others, 1996; Bromwich and others, 2000). However, knowledge of the spatial and temporal variability of climate in Antarctica is limited due to the short instrumental record. Glaciochemical records from Antarctic ice cores can be used to extend the instrumental record. High-resolution icecore records provide information on the past composition of the atmosphere, notably changes in aerosol source regions and transport pathways (Legrand and Mayewski, 1997). Marine aerosols $\left(\mathrm{Na}^{+}, \mathrm{Cl}^{-}, \mathrm{SO}_{4}{ }^{2-}, \mathrm{Mg}^{2+}, \mathrm{K}^{+}\right)$are the most abundant primary aerosol in the Antarctic troposphere, representing $\sim 80 \%$ of the ionic budget in coastal regions (Legrand and Mayewski, 1997). Marine aerosol records from Antarctic ice cores have been used to examine changes in the strength and position of low-pressure systems, sea-ice extent and wind strength (Kreutz and others, 2000b; Souney and others, 2002). Traditionally, sea spray and bubbles bursting at the ocean surface were assumed to be the only source of marine aerosols in Antarctic ice cores, but recent studies have shown that frost flowers are an important marine aerosol source (Rankin and others, 2000, 2002).

Previous studies have attributed high marine aerosol concentrations in ice cores to intensified production of aerosols associated with high wind speeds and turbulent conditions related to increased cyclonic activity (Curran and others, 1998; Kreutz and others, 2000b). Marine species in both coastal and inland ice cores have a clear seasonal signal, with highest concentrations in winter and spring (March-November), and lowest concentrations in summer (December-February). Ice-core records indicate that glacial periods have much higher marine aerosol levels than interglacial periods (Legrand and others, 1988). Thus, marine aerosol loading in Antarctica is greatest during cold periods, when greater sea-ice extent increases the distance from the core sites to open water. If the major marine aerosol source during winter is sea spray from open-water areas north of the sea-ice edge, then a more efficient transport or much higher production rate of aerosols by bubble bursting is required to account for the higher marine aerosol levels. Alternatively, higher marine aerosol loading could occur during early winter when the sea ice is not yet fully formed but winds are increasing (Souney and others, 2002).

Recent studies (Wagenbach and others, 1998; Rankin and others, 2000, 2002) suggest that a significant source of the marine aerosol budget recorded in coastal Antarctic ice-core records is highly saline frost flowers that form on the surface of new sea ice. Brine forms at the surface of new sea ice, and below $-8^{\circ} \mathrm{C}$ sodium sulfate precipitates from the brine as mirabilite $\left(\mathrm{Na}_{2} \mathrm{SO}_{4} 10 \mathrm{H}_{2} \mathrm{O}\right)$ (Richardson, 1976). This process removes most of the $\mathrm{SO}_{4}{ }^{2-}$ and up to $13 \%$ of the $\mathrm{Na}^{+}$from the brine, causing fractionation of the $\mathrm{SO}_{4}{ }^{2-}$ and $\mathrm{Na}^{+}$ (Rankin and others, 2002). The brine is wicked onto the frost flowers, which results in highly saline frost flowers depleted in $\mathrm{SO}_{4}{ }^{2-}$ relative to other marine ions that can be transported inland by winds. Previous studies (Mulvaney and Peel, 1988; Wagenbach and others, 1998) have reported depleted winter $\mathrm{SO}_{4}{ }^{2-}$ concentrations relative to other marine ions from coastal aerosol, snow and ice-core samples, indicating that frost flowers can be a significant source of marine aerosols in winter. During cold periods (winter and glacial periods) sea-ice production and sea-ice extent increases, and the available area for frost-flower production increases. Thus, the timing of increased frost-flower production coincides with the highest concentration of marine aerosols recorded in ice-core records.

Marine aerosol time series from 16 spatially distributed ice cores from West Antarctica and South Pole spanning the last $\sim 200$ years are examined in this study to investigate: primary source regions and pathways of marine aerosols; the extent to which physical parameters (distance inland, elevation) control marine aerosol concentrations; the relative 


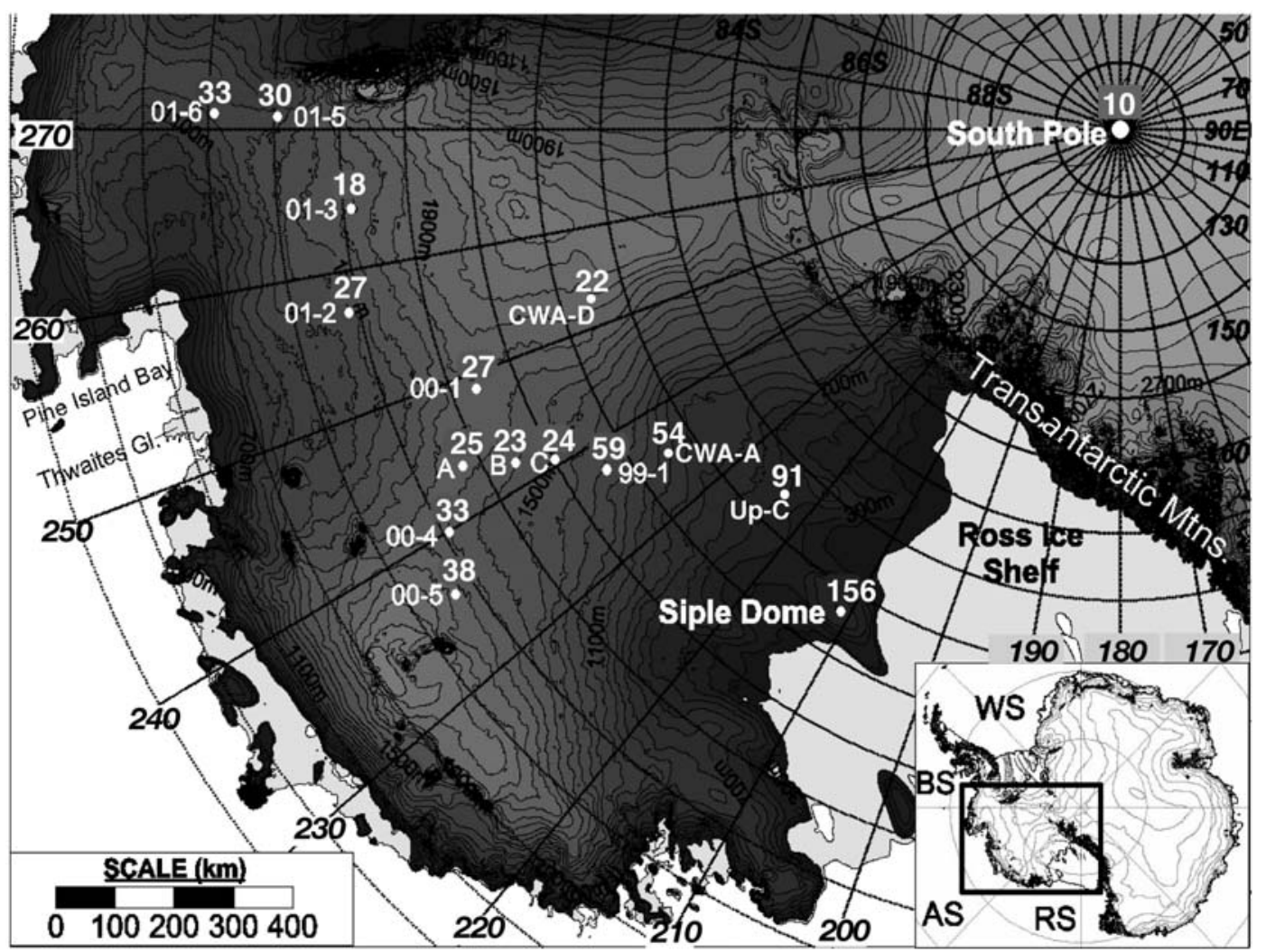

Fig. 1. Ice-core locations and mean $\mathrm{Na}^{+}$concentrations $\left(\mu \mathrm{g} \mathrm{L}^{-1}\right), 1922-90$. Core site locations: 01-06, 01-5, 01-3 and 01-2 in the Pine Island-Thwaites drainage system; 00-1, RIDS A (A), 00-4 and 00-5 near the ice divide; and RIDS B (B), RIDS C (C), 99-1, CWA-A, CWA-D, Up-C and Siple Dome in the Ross drainage system. WS: Weddell Sea; BS: Bellingshausen Sea; AS: Amundsen Sea; RS: Ross Sea. A digital elevation model was used to produce the map (Liu and others, 2001).

contributions of sea spray (open-water, unfractionated source) and frost flowers (sea-ice, fractionated source) to the marine aerosol budget; factors controlling marine aerosol production (e.g. sea-ice extent, the formation of leads and polynyas); and the relationship between atmospheric circulation strength and marine aerosol concentrations.

\section{DATA}

Eight (99-1, 00-1, 00-4, 00-5, 01-2, 01-3, 01-5 and 01-6) of the 16 ice cores used in this study were collected during the 1999-2003 phase of the United States portion of the International Trans-Antarctic Scientific Expedition (ITASE), and the remaining ice cores were collected as part of earlier investigations: RIDS A, RIDS B, RIDS C (Kreutz and Mayewski, 1999; Kreutz and others, 2000a), CWA-A, CWA-D (Reusch and others, 1999), Up-C (Dixon and others, 2004), Siple Dome (Kreutz and others, 1999) and South Pole (Meyerson and others, 2002). Cores from (Fig. 1; Table 1) sites 01-6, 01-5, 01-3 and 01-2 are located in the Pine Island-Thwaites drainage system; RIDS B, RIDS C, 99-1, CWA-A, CWA-D, Up-C and Siple Dome are located in the Ross drainage system; 00-1, RIDS A, 00-4 and 00-5 are located near the ice divide between the two drainage systems; and one core is from the South Pole. The highresolution ( $\sim 2-3 \mathrm{~cm}$ sample $^{-1}, \sim 15-50$ samples $^{-1}$ at highaccumulation sites; $\sim 6-12$ samples $^{-1}$ at South Pole) cores were sub-annually dated using seasonal maxima from chemical species $\left(\mathrm{Na}^{+}, \mathrm{K}^{+}, \mathrm{Mg}^{2+}, \mathrm{Ca}^{2+}, \mathrm{Cl}^{-}, \mathrm{NO}_{3}{ }^{-}, \mathrm{SO}_{4}{ }^{2-}\right.$, $\mathrm{Cl}^{-} / \mathrm{Na}^{+}$) (Whitlow and others, 1992) analyzed using ion chromatography (Buck and others, 1992). Clear seasonal signals are formed from peaks in sea salt $\left(\mathrm{Na}^{+}\right)$in the winter, and $\mathrm{SO}_{4}{ }^{2-}$ and $\mathrm{NO}_{3}{ }^{-}$in the summer. The dating of the records is calibrated to known volcanic horizons, and the dating accuracy for annual layers between the volcanic horizons is $\leq 1$ year for all cores (Dixon and others, 2004; Kaspari and others, 2004), except for Up-C estimated at $\leq 2$ years (personal communication from D. Dixon, 2004). The annually resolved $\mathrm{Na}^{+}$concentrations presented in this study are mean annual $\mathrm{Na}^{+}$concentrations.

Reference species are frequently used to determine seasalt contributions to the chemical signal, with the assumption that all of the reference species is unfractionated and of sea-salt origin. A marine species is unfractionated if its ratio to other marine species is the same as in standard sea water, and fractionated if its ratio to other marine species is depleted relative to standard sea water. Because $\mathrm{Cl}^{-}$interacts with gas-phase species, $\mathrm{Na}^{+}$is more commonly used as a reference species than $\mathrm{Cl}^{-}$. $\mathrm{Na}^{+}$is the conservative ion in $>90 \%$ of the samples from the 16 ice cores (Dixon and others, 2004), so $\mathrm{Na}^{+}$is used as the reference sea-salt species in this study (Fig. 2). $\mathrm{Na}^{+}$from sea salt is unfractionated, but $\mathrm{Na}^{+}$from frost flowers is fractionated during precipitation of mirabilite. Analysis of the $\mathrm{SO}_{4}{ }^{2-} / \mathrm{Na}^{+}$ ratios helps to identify the samples from the ice cores where $\mathrm{Na}^{+}$may be fractionated. Calculations of the non-sea-salt portion of the $\mathrm{SO}_{4}{ }^{2-}$ budget are made by:

$$
\left[\mathrm{nssSO}_{4}{ }^{2-}\right]=\left[\text { total } \mathrm{SO}_{4}{ }^{2-}\right]-k\left[\mathrm{Na}^{+}\right],
$$

where $k=\left(\left[\mathrm{SO}_{4}{ }^{2-}\right] /\left[\mathrm{Na}^{+}\right]\right)_{\text {standard sea water }}$ Samples with negative $\mathrm{nsSO}_{4}{ }^{2-}$ values, and thus $\mathrm{SO}_{4}{ }^{2-} / \mathrm{Na}^{+}$ratios below the standard sea-water weight ratio $(0.25)$, are assumed 

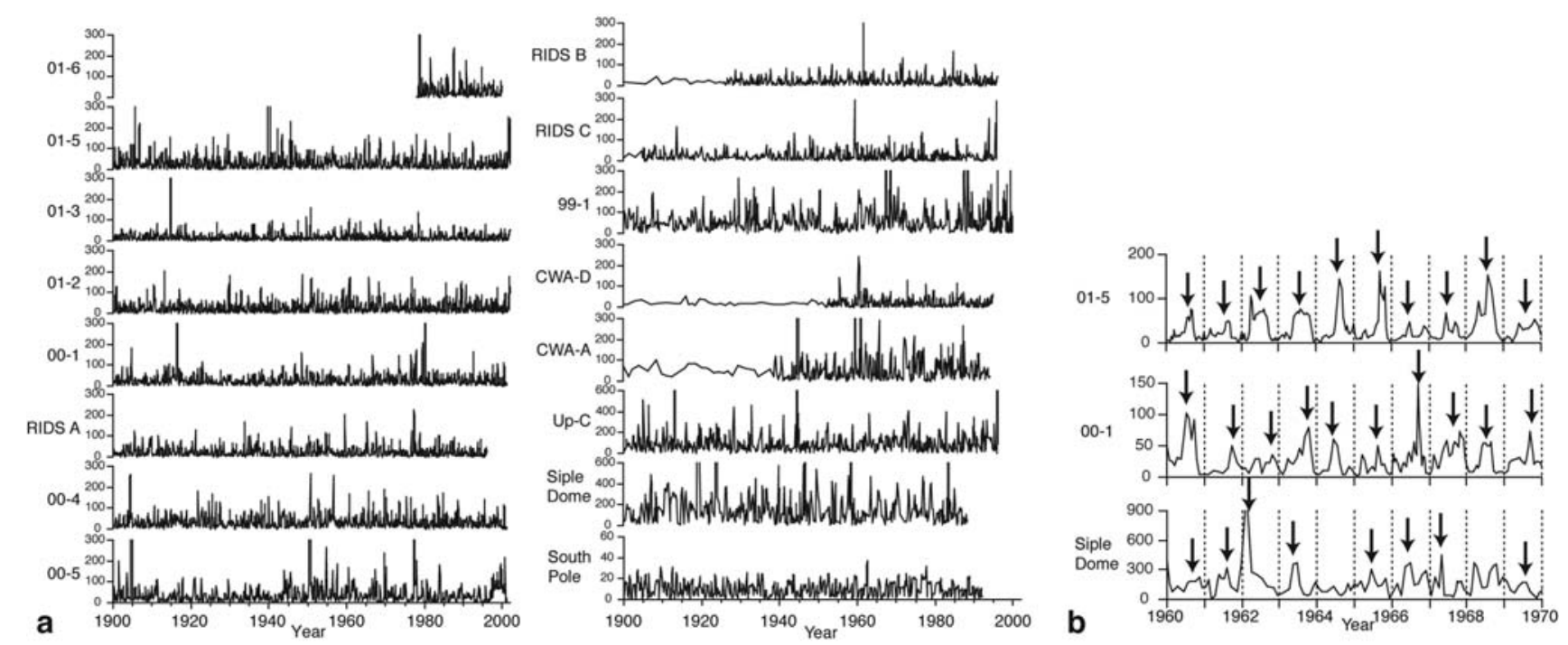

Fig. 2. (a) $\mathrm{Na}^{+}$concentrations $\left(\mu \mathrm{g} \mathrm{L}^{-1}\right), 1900-2000$. (b) $\mathrm{Na}^{+}$concentrations $\left(\mu \mathrm{g} \mathrm{L}^{-1}\right), 1960-70$ for selected sites. Arrows indicate winter-spring peaks in $\mathrm{Na}^{+}$.

to have a frost-flower source. However, additional inputs of $\mathrm{SO}_{4}{ }^{2-}$ from $\mathrm{nsSSO}_{4}{ }^{2-}$ sources (volcanic emissions, and atmospheric oxidation of biogenically produced dimethyl sulfide) could mask $\mathrm{Na}^{+}$originating from frost flowers in the record.

\section{RESULTS AND DISCUSSION}

\section{Spatial distribution of marine aerosols in West Antarctica}

The spatial distribution of $\mathrm{Na}^{+}$concentrations across West Antarctica is examined to identify the dominant source regions and pathways of marine aerosols (Fig. 1). The highest mean $\mathrm{Na}^{+}$concentrations occur in the Ross drainage system at Siple Dome $\left(156 \mu \mathrm{g} \mathrm{L}^{-1}\right), \mathrm{Up}-\mathrm{C}\left(91 \mu \mathrm{g} \mathrm{L}{ }^{-1}\right), 99-1\left(59 \mu \mathrm{g} \mathrm{L}^{-1}\right)$ and CWA-A ( $54 \mu \mathrm{g} \mathrm{L}^{-1}$ ), indicating that $\mathrm{Na}^{+}$deposition in the Ross drainage system is dominated by marine aerosols from the Ross Sea transported across the Ross Ice Shelf (Fig. 1; Table 1). In the Pine Island-Thwaites drainage system, $\mathrm{Na}^{+}$ concentrations are highest in the eastern sector (01-5 $\left(30 \mu \mathrm{g} \mathrm{L}^{-1}\right)$, 01-6 $\left.\left(33 \mu \mathrm{g} \mathrm{L}^{-1}\right)\right)$, indicating that the dominant source region is not the Ross Sea, but rather the Amundsen and Bellingshausen Seas. The ice-divide sites (00-1, RIDS A, 00-4 and 00-5) are most likely influenced by both the Ross and Amundsen-Bellingshausen Sea regions.

Previous studies identify distance inland and elevation as the main controls on the concentration of marine species in snow across Antarctica, noting that a decreasing trend in $\mathrm{Na}^{+}$concentrations vs elevation is more significant than that vs distance inland (Mulvaney and Wolff, 1994; Kreutz and Mayewski, 1999; Kreutz and others, 1999). An examination

Table 1. Site information and mean $\mathrm{Na}^{+}$concentrations. The mean $\mathrm{Na}^{+}$concentration is for the period 1922-91 for all cores except 01-6, which covers $1978-2001$. Fractionated samples have a $\mathrm{SO}_{4}{ }^{2-} / \mathrm{Na}^{+}$ratio less than the standard sea-water weight ratio $(0.25)$. $\mathrm{x}=$ not calculated

Site Time period Latitude Longitude $\quad$ Elevation $\quad \begin{gathered}\text { Distance } \\ \text { inland }\end{gathered} \quad{\text { Mean } \mathrm{Na}^{+}}_{\begin{array}{c}\% \text { of samples } \\ \text { fractionated of } \mathrm{Na}^{+} \text {budget from } \\ \text { fractionated samples }\end{array}}$

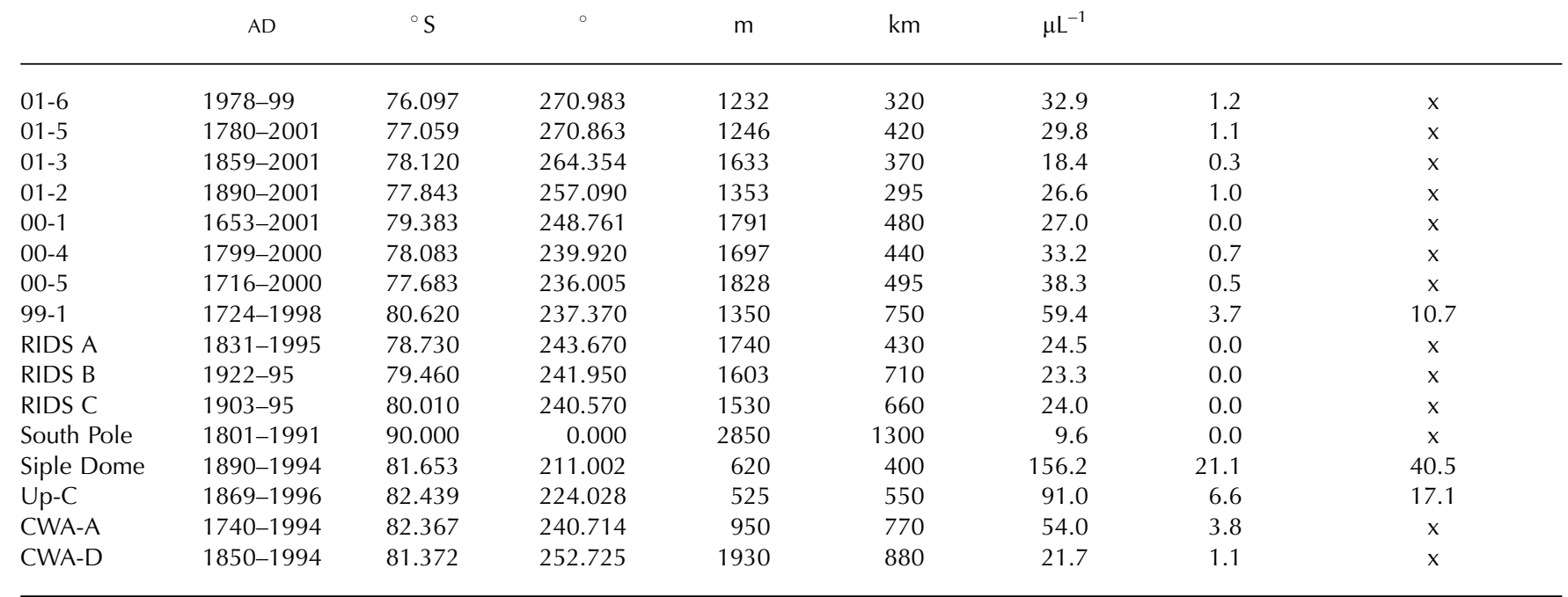



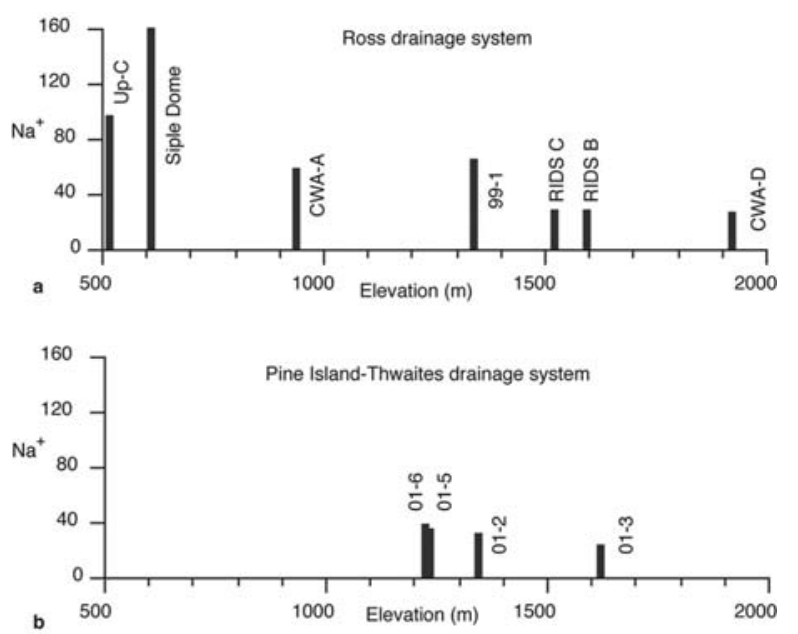

Fig. 3. Elevation (m) vs $\mathrm{Na}^{+}$concentrations $\left(\mu \mathrm{g} \mathrm{L}^{-1}\right.$ ) for Ross (a) and Pine Island-Thwaites (b) drainage systems.

of the mean $\mathrm{Na}^{+}$concentration from the 16 ice-core records vs distance inland does not show a trend, even when the drainage systems are considered independently. This may result from difficulties in identifying distance inland, because variations in atmospheric circulation patterns and sea-ice extent can change the relative distance from a location to the marine aerosol source. There is not a trend between $\mathrm{Na}^{+}$concentration and elevation across the study region. However, a decreasing trend in $\mathrm{Na}^{+}$concentrations is evident with increasing elevation when the drainage systems are considered independently (Fig. 3). This relationship does not hold for ice-divide sites, perhaps because of $\mathrm{Na}^{+}$contributions from both the Ross and AmundsenBellingshausen Seas. It is difficult to assess the relative importance of distance inland and elevation vs $\mathrm{Na}^{+}$ concentration in the study region because distance inland and elevation both vary between sites. For example, in the Ross drainage system, Siple Dome has considerably higher $\mathrm{Na}^{+}$concentrations than the lower-elevation Up-C site, likely because Siple Dome is closer to the coast (Table 1).

\section{Mechanisms controlling marine aerosol production and transport}

Factors other than distance inland or elevation contribute to the high $\mathrm{Na}^{+}$concentrations in the Ross drainage system relative to the Pine Island-Thwaites drainage system. Kreutz and Mayewski (1999) observed that the concentration of sea-salt species at Siple Dome was consistent with that at other Antarctic sites at a similar elevation, but significantly higher than at sites a similar distance inland. $\mathrm{Na}^{+}$concentrations at Up-C, 99-1 and CWA-A in the Ross drainage system are higher than at other sites at similar elevations and shorter distances inland in the Pine Island-Thwaites drainage system (01-6, 01-5, 01-3 and 01-2) (Fig. 1; Table 1). The higher $\mathrm{Na}^{+}$concentrations in the Ross drainage system could be caused by more efficient production or more intense transport of marine aerosols from the Ross Sea region.

\section{Frost flowers}

The transport of highly saline frost flowers inland is a possible mechanism leading to high $\mathrm{Na}^{+}$concentrations in the Ross drainage system. The production of frost flowers is dependent upon the rapid formation of new sea ice under cold conditions. As the sea ice freezes, a thermo-molecular pressure gradient transports brine from the ice interior toward the colder surface (Wettlaufer and Worster, 1995). Field and laboratory observations have shown that during the initial hours of new sea-ice formation the brine has a salinity of $122 \%$ at $-8{ }^{\circ} \mathrm{C}$, which increases to $212 \%$ at $-20^{\circ} \mathrm{C}$ (Richardson, 1976; Perovich and Richter-Menge, 1994). The surface brine evaporates, and creates a water-vapor layer in the atmospheric boundary layer in which enhanced crystal growth forms frost flowers (Martin and others, 1996). Surface tension results in transport of the surface brine onto the frost crystals, yielding highly saline frost flowers (Perovich and Richter-Menge, 1994). The brine and frost flowers can have salinities three times higher than sea water (Drinkwater and Crocker, 1988; Perovich and Richter-Menge, 1994; Martin and others, 1995). If frost flowers are mobilized into the atmosphere, they present a highly concentrated source of sea-salt particles (Hall and Wolff, 1998). The ideal wind speed for efficient frost-flower transport is not known; however, low winds are insufficient to allow aerosol incorporation of $\mathrm{Na}^{+}$from the flowers, and high wind speeds destroy the flowers (Rankin and others, 2000). Usually within 1-2 weeks of formation the structure of the frost-flower layer is modified by strong winds (Drinkwater and Crocker, 1988).

The salinity of frost flowers depends on the temperature at which the flowers form (Martin and others, 1996), but generally frost flowers are sodium sulfate-depleted (Rankin and others, 2002). If the ice surface temperature is cold enough, mirabilite precipitates within the ice interior, but at warmer temperatures $\left(-12\right.$ to $\left.-16^{\circ} \mathrm{C}\right)$ the mirabilite is precipitated out of a slush layer (Martin and others, 1996). $\mathrm{NaCl}$ precipitates below $-22^{\circ} \mathrm{C}$, but because ice surface temperatures this cold are usually associated with multi-year ice, frost flowers depleted in $\mathrm{NaCl}$ are not expected (Rankin and others, 2002).

The fractionation process from the precipitation of mirabilite can be expected for all sea-ice production with ice surface temperatures below $-8^{\circ} \mathrm{C}$ (Rankin and others, 2002), and under appropriate conditions at certain locations the fractionated frost-flower aerosol could dominate the seasalt budget (Rankin and others, 2000). Rankin and others (2002) calculate that $13 \%$ of the samples in an ice core from Dolleman Island on the Antarctic Peninsula have $\mathrm{SO}_{4}{ }^{2-} / \mathrm{Na}^{+}$ ratios less than the standard sea-water weight ratio (suggesting a frost-flower source); however, those samples account for $39 \%$ of the $\mathrm{Na}^{+}$in the core. Similar analysis is conducted on the ice-core records from this study. The percentage of the total $\mathrm{Na}^{+}$budget that is fractionated is calculated by:

$$
\begin{aligned}
& \mathrm{Na}^{+}{ }_{\text {total }}=\Sigma\left(\mathrm{Na}^{+}{ }_{\text {sample }}\right)\left(\text { mass }_{\text {sample }}\right) \\
& \mathrm{Na}^{+} \text {fractionated } \\
& =\Sigma\left(\mathrm{Na}^{+}{ }_{\text {fractionated sample }}\right)\left(\text { mass }_{\text {fractionated sample }}\right) \\
& \% \mathrm{Na}^{+}{ }_{\text {fractionated }}=\left(\mathrm{Na}^{+}{ }_{\text {fractionated }} / \mathrm{Na}^{+}{ }_{\text {total }}\right)(100) .
\end{aligned}
$$

A fractionated sample is defined as having a $\mathrm{SO}_{4}{ }^{2-} / \mathrm{Na}^{+}$ weight ratio less than the standard sea-water weight ratio. Mass was estimated for the Up-C core because density measurements were not taken, and the percentage of the $\mathrm{Na}^{+}$budget that the fractionated samples account for at CWA-A is not calculated because density and depth measurements were not taken. Of the total samples, $21 \%$ at Siple Dome, $7 \%$ at Up-C, $4 \%$ at $99-1$, and $4 \%$ at CWA-A are fractionated, yet this accounts for $40 \%, 17 \%$ and $10 \%$ of the total $\mathrm{Na}^{+}$in the Siple Dome, Up-C and 99-1 cores, 
respectively (Table 1 ). The samples with $\mathrm{SO}_{4}{ }^{2-} / \mathrm{Na}^{+}$less than the standard sea-water weight ratio account for a disproportionately high percentage of the total $\mathrm{Na}^{+}$budget.

Calculations of fractionated samples may underestimate $\mathrm{Na}^{+}$with a frost-flower source because inputs from marine biogenic or volcanic $\mathrm{SO}_{4}{ }^{2-}$ could increase the ratios above that of standard sea water (Rankin and others, 2002). Longrange transport of marine biogenic $\mathrm{SO}_{4}{ }^{2-}$ from mid-latitude sources can occur throughout the year, but the highest contributions are during summer (Minikin and others, 1998). Because frost-flower contributions to the $\mathrm{SO}_{4}{ }^{2-}$ budget are greatest during winter, and biogenic inputs are greatest during summer, there is likely a low occurrence of biogenic $\mathrm{SO}_{4}{ }^{2-}$ inputs masking the evidence of frost flowers. Volcanic inputs to the $\mathrm{SO}_{4}{ }^{2-}$ budget more strongly influence the sites with elevations above $1000 \mathrm{~m}$ (Dixon and others, 2004). Siple Dome, Up-C and CWA-A, all with elevations below $1000 \mathrm{~m}$ (Table 1), are the sites with the greatest occurrence of depleted $\mathrm{SO}_{4}{ }^{2-} / \mathrm{Na}^{+}$ratios. This suggests that volcanic inputs to the $\mathrm{SO}_{4}{ }^{2-}$ budget at the higher-elevation sites may be masking evidence of frost flowers. However, volcanic inputs are episodic (Dixon and others, 2004), so evidence of frost flowers should be apparent during periods with no volcanic inputs.

Periods of $\mathrm{SO}_{4}{ }^{2-} / \mathrm{Na}^{+}$ratios below the standard sea-water weight ratio generally coincide with high winter $\mathrm{Na}^{+}$ concentrations (Fig. 4). Analysis of the Siple Dome $\mathrm{SO}_{4}{ }^{2-}$ $\mathrm{Na}^{+}$time series indicates fractionated samples for 30 of the 44 winters between 1950 and 1994. Frost flowers may be a significant source of $\mathrm{Na}^{+}$during every winter, but inputs from biogenic or volcanic $\mathrm{SO}_{4}{ }^{2-}$ could mask evidence of the frost flowers. The higher prevalence of fractionated samples at Siple Dome than at the other core sites is likely caused by higher deposition of frost flowers, and/or relatively less $\mathrm{nssSO}_{4}{ }^{2-}$ contributions in winter resulting in fewer masked samples.

Siple Dome, Up-C, 99-1 and CWA-A (all located in the Ross drainage system) have the highest $\mathrm{Na}^{+}$concentrations in the study area, and the low $\mathrm{SO}_{4}{ }^{2-} / \mathrm{Na}^{+}$ratios at these sites suggest frost flowers as a $\mathrm{Na}^{+}$source (Table 1). Therefore, transport of highly saline frost-flower aerosols into the Ross drainage system may be the cause of the high $\mathrm{Na}^{+}$ concentrations at these sites. The size of frost-flower aerosols in part determines the distance the aerosols can be transported. Previous work at Halley research station in the Weddell Sea region indicates that frost-flower aerosols are generally in the super-micron range, but may also be present as very small particles (Rankin and Wolff, 2003). The evidence of frost-flower aerosols at 99-1 and CWA-A indicates that the frost-flower aerosols are transported long distances and to high elevations, and suggests that at these sites the frost-flower aerosols are present as small particles. In contrast, there is minimal evidence of frost flowers in the ice-core records from the Pine Island-Thwaites drainage system $(01-5,01-3,01-2)$ (Table 1). The distance inland at 01-5 and 01-2 is less than at Siple Dome, Up-C, 99-1 and CWA-A, and the elevation at 01-5 and 01-2 is similar to that at 99-1, so there must be factors other than distance inland or elevation controlling frost-flower transport into the Ross drainage system. This could be a consequence of different frost-flower production rates in the Ross Sea relative to the Amundsen-Bellingshausen Seas. Alternatively, additional $\mathrm{nssSO}_{4}{ }^{2-}$ inputs in the Pine Island-Thwaites drainage system could be masking the evidence of frost flowers in these ice
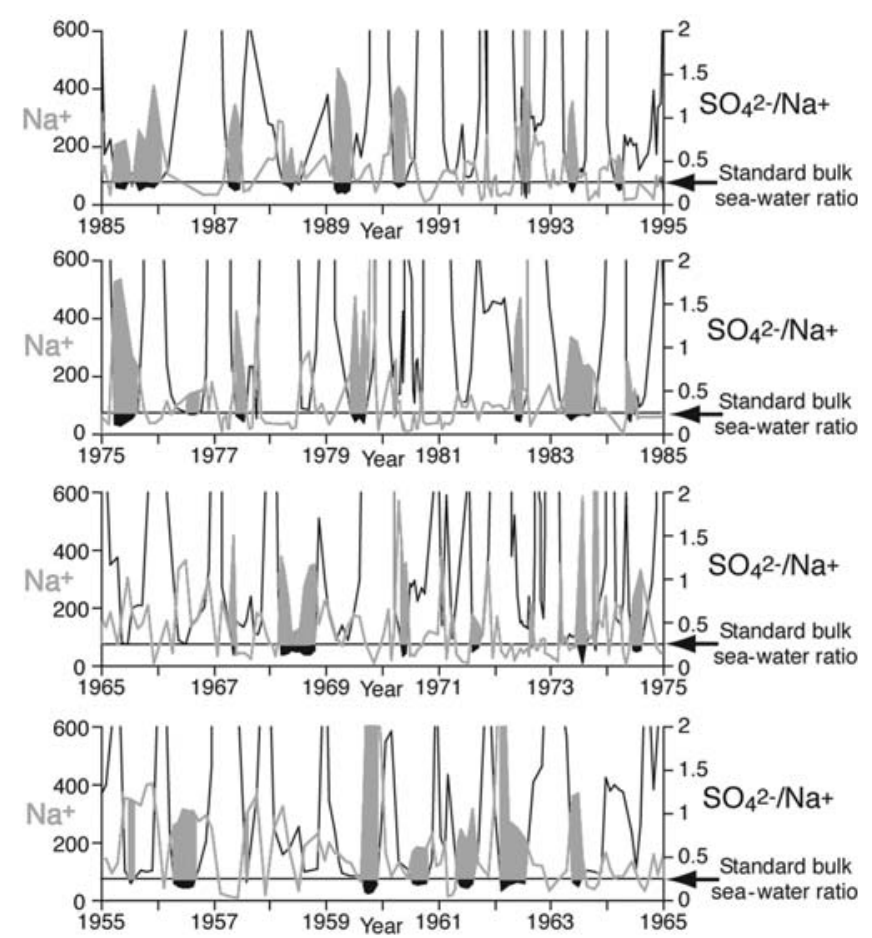

Fig. 4. Siple Dome $\mathrm{Na}^{+}$concentrations $\left(\mu \mathrm{gL}^{-1}\right.$ ) (gray line) and $\mathrm{SO}_{4}{ }^{2-} / \mathrm{Na}^{+}$ratios (black line). $\mathrm{SO}_{4}{ }^{2-} / \mathrm{Na}^{+}$ratios below the standard bulk sea-water ratio (0.25) are black filled, and the gray filled areas are the $\mathrm{Na}^{+}$peaks.

cores, but this does not explain the lower $\mathrm{Na}^{+}$concentrations in the Pine Island-Thwaites drainage system relative to the Ross drainage system.

\section{Sea ice}

Examination of the mean annual $\mathrm{Na}^{+}$distribution map (Fig. 1) suggests that the Ross Sea is the dominant $\mathrm{Na}^{+}$source region for sites located in the Ross drainage system. This, coupled with evidence for frost flowers at Siple Dome, $\mathrm{Up}-\mathrm{C}, 99-1$ and CWA-A based on their low $\mathrm{SO}_{4}{ }^{2-} / \mathrm{Na}^{+}$ ratios, suggests that the Ross Sea may be a larger source region for frost-flower formation than the adjoining Amundsen and Bellingshausen Seas.

Degrees latitude of sea ice (determined from land to the sea-ice edge) were calculated using mean monthly and annual time series of sea-ice extent in $10^{\circ}$-wide sections (Simmonds and Jacka, 1995) from 1973 to 1996 from 130 to $280^{\circ}$ to examine the relative extent of sea ice in the Ross, Amundsen and Bellingshausen Seas. Degrees latitude of seaice extent for September (when sea ice is at or near its maximum) and the annual mean are greater in the Ross Sea than in the Amundsen and Bellingshausen Seas (Fig. 5). This may in part explain the higher $\mathrm{Na}^{+}$concentrations at Siple Dome and 99-1, because the greater sea-ice extent may enable greater production of frost flowers.

Monthly and annual time series of sea-ice extent from 1973 to 1996 (Simmonds and Jacka, 1995) were tested for correlations with the mean annual $\mathrm{Na}^{+}$time series for all core sites. Significant correlations over a large region and in consecutive months suggest a strong relationship between sea-ice extent and aerosol transport to the core sites. Positive correlations indicate increased sea-ice extent when $\mathrm{Na}^{+}$ concentrations are high. Large differences in correlations 


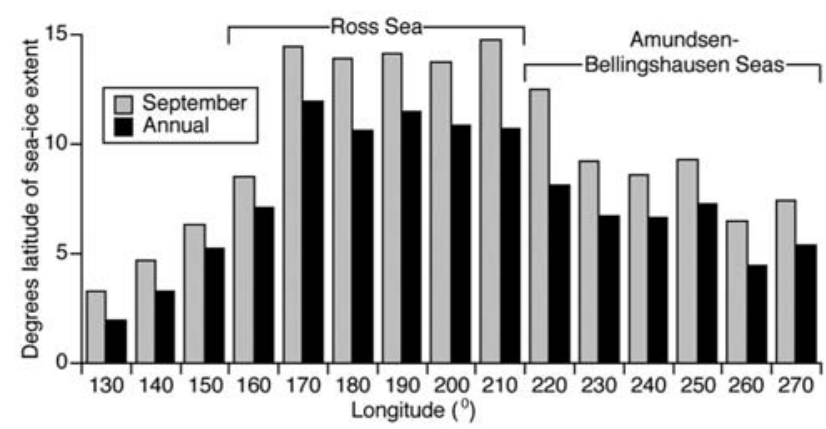

Fig. 5. Degrees latitude of sea-ice extent from the coast to the seaice edge for September and the annual average for $10^{\circ}$ sections of longitude. Sea-ice extent is greatest in the Ross Sea.

exist between the sites due to high spatial variability (Figs 1 and 2). Significant positive correlations between $\mathrm{Na}^{+}$ concentrations and sea-ice extent exist for Siple Dome $(n=22, p=0.05, r>0.36)$ during winter months (MayJuly) between $180^{\circ}$ and $240^{\circ}$ (Fig. 6). The Siple Dome correlations do not exist during all three months across all latitude bands, and the strongest correlations are farther east than expected $\left(220-240^{\circ}\right)$ based on the assumption that the majority of $\mathrm{Na}^{+}$at Siple Dome comes from the Ross Sea region. Thus, the strength of the relationship between sea-ice extent and $\mathrm{Na}^{+}$at Siple Dome is not extremely robust. Significant correlations of mean annual sea-ice extent and $\mathrm{Na}^{+}$concentrations exist at RIDS A $(n=23, p=0.05$, $r>0.35)$ between $240^{\circ}$ and $280^{\circ}$, at RIDS B $(n=23$, $p=0.05, r>0.35)$ between $220^{\circ}$ and $240^{\circ}$, and at CWA-D between $230^{\circ}$ and $280^{\circ}(n=22, p=0.05, r>0.36)$ (Fig. 7). Dixon and others (2005) report significant correlations of $\mathrm{SsSO}_{4}{ }^{2-}$ and sea-ice extent at the same sites. Correlations between sea-ice extent and RIDS A, RIDS B and CWA-D suggest that marine aerosol concentrations in the central part of West Antarctica are linked to sea-ice extent. The correlations for RIDS A and CWA-D are strongest in the region between $240^{\circ}$ and $280^{\circ}$, suggesting that RIDS $A$ and CWA-D are associated with the Bellingshausen and East Amundsen Seas. The RIDS B correlations are strongest between $220^{\circ}$ and $240^{\circ}$, suggesting an association with the West Amundsen and Ross Seas. The regions where the correlations are strongest may indicate the dominant source of the aerosols.

The production of frost flowers is physically linked with the formation of new sea ice rather than present ice extent, so correlations of new sea ice and mean $\mathrm{Na}^{+}$concentrations were also tested for. New sea ice was determined by taking the difference between the greatest (usually September) and least (usually January) sea-ice extent for each year and $10^{\circ}$-wide sections. These results confirm the findings from the correlations of mean annual sea-ice extent and $\mathrm{Na}^{+}$ concentrations: significant correlations of new sea ice and mean annual $\mathrm{Na}^{+}$concentrations exist at RIDS B $(n=23$, $p=0.05, r>0.35$ ) between $240^{\circ}$ and $250^{\circ}$, and at CWA-D $(n=22, p=0.05, r>0.36)$ between $250^{\circ}$ and $270^{\circ}$. Increased $\mathrm{Na}^{+}$concentrations during periods of increased sea-ice production and extent may indicate greater production and transport of frost-flower aerosols, but it is not known why $\mathrm{Na}^{+}$concentrations in the central region of the study area are associated with sea ice whereas similar correlations are not found at other nearby cores. Possible

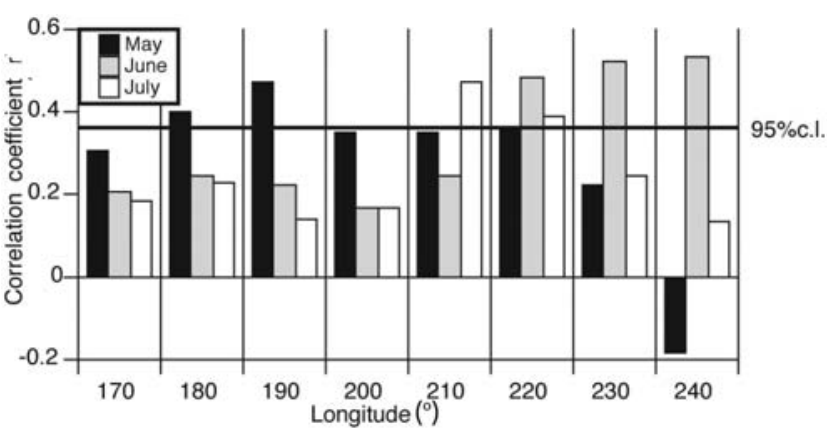

Fig. 6. Correlation coefficients $(r)$ of monthly (May-July) sea-ice extent, 1973-96, in $10^{\circ}$ sections of longitude and the mean annual Siple Dome $\mathrm{Na}^{+}$record.

mechanisms for the marine-aerosol-sea-ice association include sensitivity to sea-ice duration, overall extent and seasonal or annual variability.

\section{Open-water areas}

Frost-flower formation is associated with the development of young sea ice; thus, as sea ice ages and thickens, the production of frost flowers ceases. As a consequence, seaice extent may not be the best indicator of frost-flower production. Wagenbach and others (1998) identified polynyas and leads as potential open-water sources for winter marine aerosols. Leads typically open to widths of tens to hundreds of meters (Perovich and Richter-Menge, 1994), and polynyas can be thousands of square kilometers (Arrigo and Van Dijken, 2003b). These regions could be sources of marine aerosols from both frost flowers and sea spray. The presence of open-water features within the sea ice may allow continual production of frost flowers throughout the year. In these open areas, heat loss to the atmosphere from the relatively warm ocean water reaches a maximum and results in the rapid growth of ice. Katabatic winds can drive extremely high rates of sea-ice production in polynyas because older sea ice is continually blown offshore and replaced by new sea ice (Arrigo and Van Dijken, 2003b).

Variations in the formation and presence of leads and polynyas in the Ross, Amundsen and Bellingshausen Seas could in part explain why the Ross drainage-site data indicate a frost-flower source when other core sites do not. Currently, there is no available information to indicate that there is greater lead formation in the Ross Sea than in the Amundsen-Bellingshausen region. The Ross Sea does, however, have considerably more open water due to the presence of the Ross Sea polynya. The Ross Sea polynya is the largest in Antarctica (summer area $396500 \mathrm{~km}^{2}$, winter area $19600 \mathrm{~km}^{2}$; Arrigo and Van Dijken, 2003b). Six smaller polynyas have been identified in the AmundsenBellingshausen region (Sulzberger Bay, Hull Bay, Wrigley Gulf, Amundsen Sea, Pine Island Bay, Eltanin Bay), but their total combined area (summer area $103100 \mathrm{~km}^{2}$, winter area $12880 \mathrm{~km}^{2}$; Arrigo and Van Dijken, 2003b) is still considerably smaller than that of the Ross Sea polynya. Thus, the Ross Sea polynya may be a significant source of marine aerosols for the Ross drainage system from sea spray and frost flowers. Correlations of the annually resolved $\mathrm{Na}^{+}$records and a time series of the Ross Sea polynya area from 1978 to 1994 (Arrigo and Van Dijken, 2003a) were examined to look for associations between polynya size and marine aerosol 


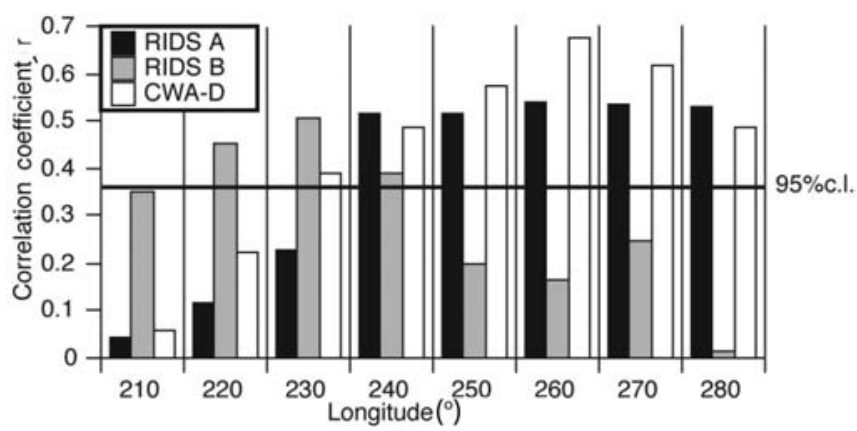

Fig. 7. Correlation coefficients $(r)$ of mean annual sea-ice extent, 1973-96, in $10^{\circ}$ sections of longitude and the mean annual $\mathrm{Na}^{+}$ records from RIDS A, RIDS B and CWA-D.

transport, but no significant associations were found. The seasonal variations in the size of the Ross Sea polynya are much greater than interannual variations, and sea-ice (and thus frost-flower) production is controlled more by wind and temperature conditions than by interannual variations in polynya size, which may explain the lack of significant $\mathrm{Na}^{+}$-concentration-polynya-size associations.

\section{Atmospheric circulation}

Although there is compelling evidence that frost flowers are a major contributor to the $\mathrm{Na}^{+}$budget, sea spray from openwater sources remains an important source of $\mathrm{Na}^{+}$. Changes in atmospheric circulation caused by shifts in the position and deepening of low-pressure systems on seasonal and longer timescales alter the pathways that transport marine aerosols inland (Kreutz and others, 2000b).

Wind speeds are strongest in the winter months, with the strongest winds in the Ross drainage region of the study area (Kalnay and others, 1996; King and Turner, 1997). High $\mathrm{Na}^{+}$ concentrations in the winter (Fig. 2) coupled with the higher wind speeds suggest that stronger winds transport more marine aerosols. The dominant wind direction in the Ross drainage system comes from katabatic winds from inland Antarctica that cause consistently more turbulent conditions at the boundary layer. These turbulent conditions ultimately may result in greater production and transport of aerosols from sea spray. Less dominant northerly winds likely transport most of the marine aerosols into the Ross drainage system from the Ross Sea. Increased aerosols from sea spray coupled with greater frost-flower production in the winter months would result in higher $\mathrm{Na}^{+}$concentrations.

The influence of atmospheric circulation on the production of marine aerosols and their transport into West Antarctica is assessed by examining associations between sea-level pressure (SLP) from the US National Centers for Environmental Prediction (NCEP) re-analysis (Kalnay and others, 1996) and the $\mathrm{Na}^{+}$time series. Previous studies found strong associations between SLP and marine aerosol variability (Kreutz and others, 2000b; Souney and others, 2002). To investigate the relationship between SLP and the $\mathrm{Na}^{+}$time series from the ice cores in this study, a method similar to Kreutz and others' $(2000 a, b)$ is used in which years of high and low marine aerosol transport are defined as being at least $\pm 1 \sigma$ from the $\mathrm{Na}^{+}$mean (calculated for the period 1948-present) for each record. Low- $\mathrm{Na}^{+}$-year NCEP SLP fields are subtracted from high- $\mathrm{Na}^{+}$-year NCEP SLP fields (Fig. 8). Negative differences in SLP in the Ross,

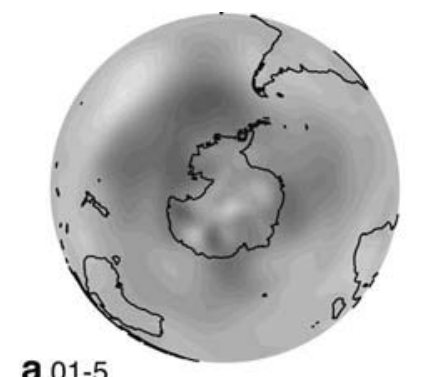

a $01-5$
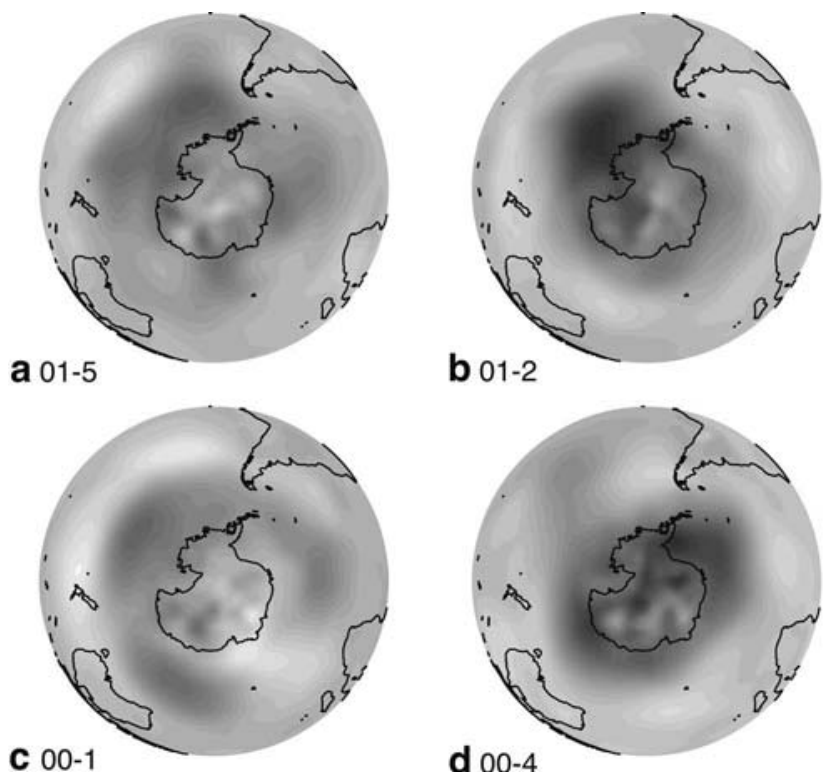

b $01-2$
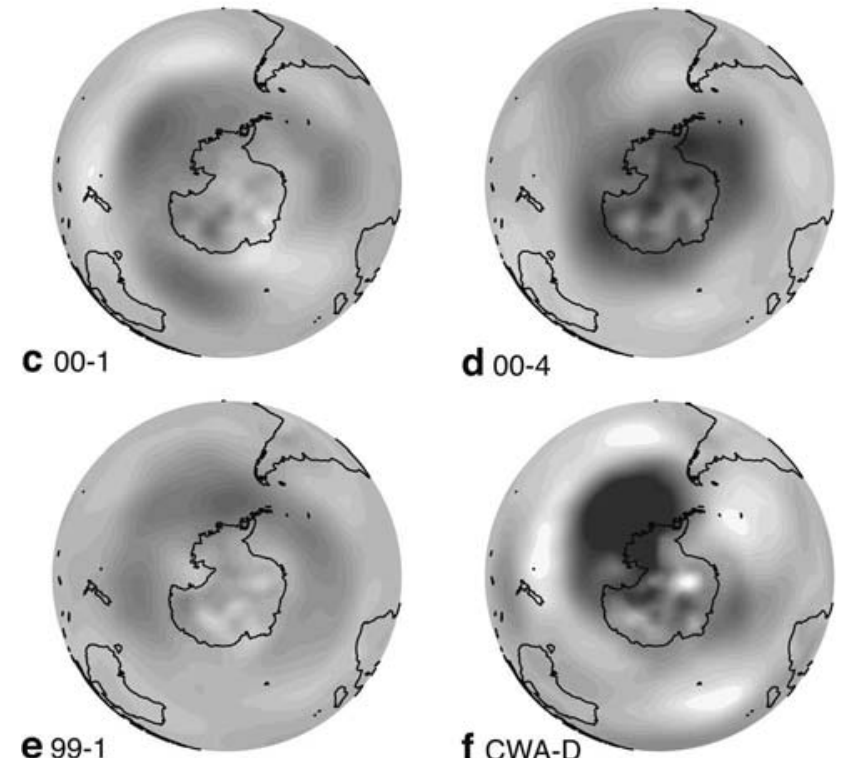

d $00-4$
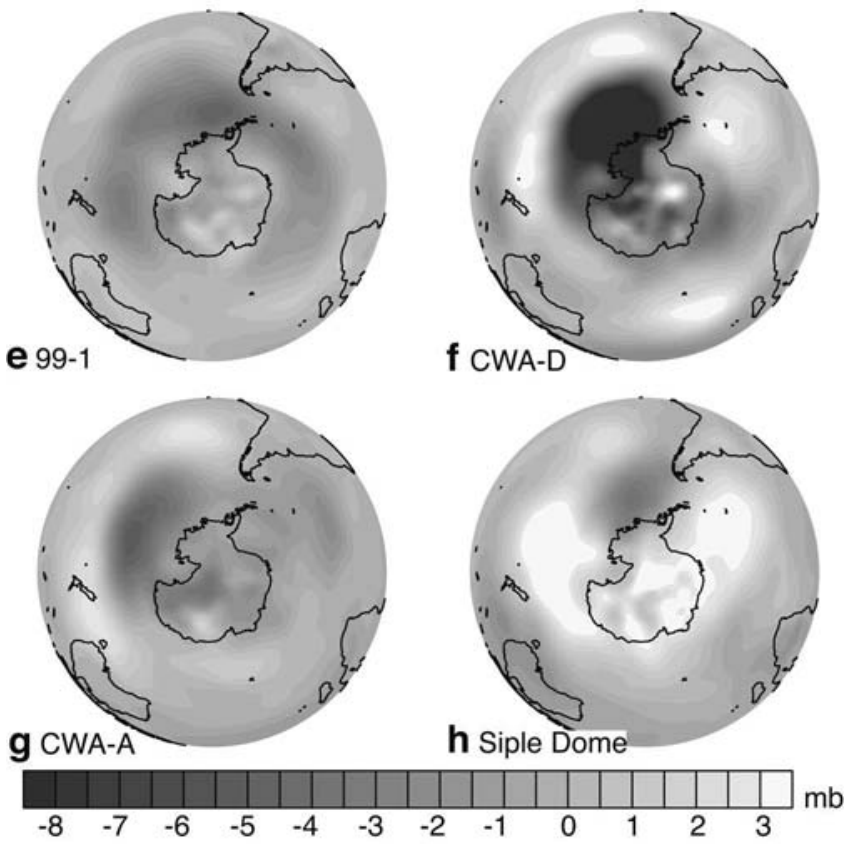

Fig. 8. Mean September-November SLP differences plotted in millibars derived from the US National Centers for Environmental Prediction/US National Center for Atmospheric Research (NCEP/ NCAR) re-analysis. Method used to select years is described in the text.

Amundsen and Bellingshausen Seas for core sites 01-5, 01-2, 00-1, 00-4, 99-1, CWA-D, CWA-A and Siple Dome indicate increased transport of marine aerosols to these sites when SLP is low. This relationship is strongest during September-November, in agreement with Kreutz and others' (2000a, b) results (Fig. 8). The negative differences in SLP for Ross drainage-system sites (99-1 and Siple Dome) are comparatively small, perhaps because $\mathrm{Na}^{+}$concentrations at these sites are more strongly influenced by frost-flower production than by atmospheric circulation. This method did not result in significant differences in SLP fields for the other core sites (01-3, RIDS A, RIDS B, RIDS C, 00-5, Up-C and South Pole), perhaps because of additional factors controlling $\mathrm{Na}^{+}$deposition at these sites (e.g. blocking high effects, blocking by katabatic winds, core-dating errors). 
More notably, the sites that do have strong SLP-Na+ associations (01-5, 01-2, 00-1, 00-4, 99-1, CWA-D, CWAA and Siple Dome) are distributed throughout the study area, indicating that SLP influences marine aerosol transport across West Antarctica. Years of high and low $\mathrm{Na}^{+}$concentrations vary between sites, which may result from shifts in the position of the Amundsen Sea low (ASL), a climatological feature associated with cyclonic activity and the transport of moisture and aerosols into West Antarctica. The position of the ASL can migrate $\sim 1400 \mathrm{~km}$ on an annual basis, moving between a position near the eastern Ross Ice Shelf and the Antarctic Peninsula (Cullather and others, 1996). When the ASL is positioned near the Ross Ice Shelf, cyclonic activity in that region may result in increased marine aerosol transport to the Ross drainage system, whereas when the ASL is positioned near the Antarctic Peninsula, cyclonic activity in that region may result in increased marine aerosol transport to the Pine IslandThwaites drainage system. Thus, in a simplified system a see-saw relationship may exist in which marine aerosol loadings increase (decrease) in the western section of West Antarctica and decrease (increase) in the eastern sector, depending on the positioning of the ASL (Cullather and others, 1996). Future research is needed to develop an even more robust deconvolution of the marine aerosol signal and resultant ice-core marine series.

\section{CONCLUSIONS}

The 16 spatially distributed ice cores presented in this study enable characterization of the dominant pathways by which marine aerosols are generated and transported inland to West Antarctica. The dominant source of marine aerosols to the Pine Island-Thwaites drainage system is from the Amundsen and Bellingshausen Seas, whereas marine aerosols from the Ross Sea dominate the Ross drainage system. With these records it is possible to examine regional variations in atmospheric circulation, and ocean and seaice conditions.

The results of this study are consistent with recent studies (Rankin and others, 2002) indicating that frost flowers can contribute significantly to the $\mathrm{Na}^{+}$budget of Antarctic ice cores. The $\mathrm{SO}_{4}{ }^{2-} / \mathrm{Na}^{+}$ratios from the 16 ice-core records indicate that frost flowers make significantly greater contributions to the $\mathrm{Na}^{+}$budget in the Ross drainage system than in the Pine Island-Thwaites drainage system. It is possible that relatively higher $\mathrm{SO}_{4}{ }^{2-}$ inputs from volcanic emissions or biogenically produced dimethyl sulfide in the Pine Island-Thwaites drainage system could be masking the evidence of frost flowers. However, the results from this study suggest that different conditions in the Ross Sea (greater sea-ice extent and the presence of the large Ross Sea polynya) compared to the Amundsen and Bellingshausen Seas account for the discrepancy in $\mathrm{Na}^{+}$concentrations derived from frost flowers. Because frost-flower aerosols are estimated to be three times more saline than sea-spray aerosols (Perovich and Richter-Menge, 1994; Martin and others, 1995; Drinkwater and Crocker, 1998), the higher $\mathrm{Na}^{+}$concentrations in the Ross drainage system are likely the result of greater contributions to the $\mathrm{Na}^{+}$budget by highly saline frost flowers.

Sea-ice extent in the Ross Sea is greater than in the Amundsen or Bellingshausen Sea. The greater sea-ice area may enable greater frost-flower production, leading to the higher $\mathrm{Na}^{+}$concentrations observed in the Ross drainage system. Correlations of sea-ice extent and the Siple Dome, RIDS A, RIDS B and CWA-D Na+ records suggest that, at least in some regions of West Antarctica, $\mathrm{Na}^{+}$increases when sea-ice extent increases. This lends further support to the hypothesis that greater sea-ice extent leads to increased frost-flower production, and consequently higher $\mathrm{Na}^{+}$ concentrations.

The presence of open-water features (leads and polynyas) in the sea ice during winter may be the largest source of marine aerosols in West Antarctica from both sea spray and frost flowers. The open-water areas enable continual development of new sea ice, and thus production of frost flowers, particularly in the winter when new ice development can be rapid. The Ross Sea polynya is by far the largest open-water feature in the study area, and its proximity to the Ross drainage system may explain the higher $\mathrm{Na}^{+}$concentrations observed in that region.

The transport of marine aerosols into Antarctica, regardless of whether the source is from sea spray or frost flowers, is dependent upon wind speed and direction. That $\mathrm{Na}^{+}$ concentrations are highest in the winter when the winds are strongest does not in itself imply causation; higher frostflower production in the winter can also cause increased $\mathrm{Na}^{+}$concentrations, and high $\mathrm{Na}^{+}$concentrations have been reported under moderate wind conditions at coastal sites. However, the SLP- $\mathrm{Na}^{+}$associations, which indicate higher $\mathrm{Na}^{+}$concentrations when SLP is lower, do indicate that stronger atmospheric circulation contributes to elevated $\mathrm{Na}^{+}$ concentrations. Intensified atmospheric circulation causes turbulent boundary conditions in winter, resulting in greater production of sea-spray aerosols, and/or enhanced transport of frost-flower and sea-spray aerosols.

Both sea spray and frost flowers are sources of $\mathrm{Na}^{+}$in ice cores, but it is difficult to differentiate their contributions to the $\mathrm{Na}^{+}$budget. It is possible to estimate the minimum contribution from frost flowers by the method used in this study, but additional $\mathrm{nssSO}_{4}{ }^{2-}$ inputs make it difficult to quantify the $\mathrm{Na}^{+}$contributions from both sources. The $\mathrm{Na}^{+}$ time series are related to sea-ice conditions and atmospheric circulation. If the contributing $\mathrm{Na}^{+}$sources could be separated, the $\mathrm{Na}^{+}$time series could be used as an indicator of both sea-ice conditions and SLP, and thus be more valuable as a proxy climate record. Incorporating methanesulfonate measurements in future studies may help to further differentiate marine aerosol sources.

\section{REFERENCES}

Arrigo, K.R. and G.L. van Dijken. 2003a. Impact of iceberg C-19 on Ross Sea primary production. Geophys. Res. Lett., 30(16), 1836. (10.1029/2003GL017721.)

Arrigo, K.R. and G.L. van Dijken. 2003b. Phytoplankton dynamics within 37 Antarctic coastal polynya systems. J. Geophys. Res., 108(C8), 3271. (10.1029/2002JC001739.)

Bromwich, D.H., A.N. Rogers, P. Kållberg, R.I. Cullather, J.W.C. White and K.J. Kreutz. 2000. ECMWF analyses and reanalyses depiction of ENSO signal in Antarctic precipitation. J. Climate, 13(8), 1406-1420.

Buck, C.F., P.A. Mayewski, M.J. Spencer, S. Whitlow, M.S. Twickler and D. Barrett. 1992. Determination of major ions in snow and ice cores by ion chromatography. J. Chromatogr., 594(1-2), 225-228.

Cullather, R.I., D.H. Bromwich and M.L. van Woert. 1996. Interannual variations in Antarctic precipitation related to 
El-Niño-Southern Oscillation. J. Geophys. Res., 101(D14), 19,109-19,118.

Curran, M.A.J., T.D. van Ommen and V. Morgan. 1998. Seasonal characteristics of the major ions in the high-accumulation Dome Summit South ice core, Law Dome, Antarctica. Ann. Glaciol., 27, 385-390.

Dixon, D., P.A. Mayewski, S. Kaspari, S. Sneed and M. Handley. 2004. A 200-year sub-annual record of sulfate in West Antarctica from 16 ice cores. Ann. Glaciol., 39, 545-556.

Dixon, D. and 6 others. 2005. A 200-year sulfate record from 16 Antarctic ice cores and associations with Southern Ocean seaice extent. Ann. Glaciol., 41 (see paper in this volume).

Drinkwater, M.R. and G.B. Crocker. 1988. Modelling changes in the dielectric and scattering properties of young snow-covered sea ice at $\mathrm{GHz}$ frequencies. J. Glaciol., 34(118), 274-282.

Hall, J.S. and E.W. Wolff. 1998. Causes of seasonal and daily variations in aerosol sea-salt concentrations at a coastal Antarctic station. Atmos. Environ., 32(21), 3669-3677.

Kalnay, E. and 21 others. 1996. The NCEP/NCAR 40-year reanalysis project. Bull. Am. Meteorol. Soc., 77(3), 437-471.

Kaspari, S. and 6 others. 2004. Climate variability in West Antarctica derived from annual accumulation rate records from ITASE firn/ice cores. Ann. Glaciol., 39, 585-594.

King, J.C. and J. Turner. 1997. Antarctic meteorology and climatology. Cambridge, etc., Cambridge University Press.

Kreutz, K.J. and P.A. Mayewski. 1999. Spatial variability of Antarctic surface snow glaciochemistry: implications for paleoatmospheric circulation reconstructions. Antarct. Sci., 11(1), 105-118.

Kreutz, K.J. and 11 others. 1999. Seasonal variations of glaciochemical, isotopic and stratigraphic properties in Siple Dome (Antarctica) surface snow. Ann. Glaciol., 29, 38-44.

Kreutz, K.J., P.A. Mayewski, L.D. Meeker, M.S. Twickler and S.I. Whitlow. 2000a. The effect of spatial and temporal accumulation rate variability in West Antarctica on soluble ion deposition. Geophys. Res. Lett., 27(16), 2517-2520.

Kreutz, K.J., P.A. Mayewski, I.I. Pittalwala, L.D. Meeker, M.S. Twickler and S.I. Whitlow. 2000b. Sea level pressure variability in the Amundsen Sea region inferred from a West Antarctic glaciochemical record. J. Geophys. Res., 105(D3), 4047-4059.

Legrand, M. and P. Mayewski. 1997. Glaciochemistry of polar ice cores: a review. Rev. Geophys., 35(3), 219-243.

Legrand, M.R., C. Lorius, N.I. Barkov and V.N. Petrov. 1988. Vostok (Antarctica) ice core: atmospheric chemistry changes over the last climatic cycle (160,000 years). Atmos. Environ., 22(2), 317-331.

Liu, H., K.C. Jezek, B. Li and Z. Zhao. 2001. RADARSAT Antarctic Mapping Project digital elevation model. Version 2. Boulder, CO, National Snow and Ice Data Center.

Martin, S., R. Drucker and M. Fort. 1995. A laboratory study of frost flower growth on the surface of young sea ice. J. Geophys. Res., 100(C4), 7027-7036.
Martin, S., Y. Yu and R. Drucker. 1996. The temperature dependence of frost flower growth on laboratory sea ice and the effect of the flowers on infrared observations of the surface. J. Geophys. Res., 101(C5), 12,111-12,125.

Meyerson, E.A., P.A. Mayewski, K.J. Kreutz, L.D. Meeker, S.I. Whitlow and M.S. Twickler. 2002. The polar expression of ENSO and sea-ice variability as recorded in a South Pole ice core. Ann. Glaciol., 35, 430-436.

Minikin, A. and 7 others. 1998. Sulfur-containing species (sulfate and methanesulfonate) in coastal Antarctic aerosol and precipitation. J. Geophys. Res., 103(D9), 10,975-10,990.

Mulvaney, R. and D.A. Peel. 1988. Anions and cations in ice cores from Dolleman Island and the Palmer Land plateau, Antarctic Peninsula. Ann. Glaciol., 10, 121-125.

Mulvaney, R. and E.W. Wolff. 1994. Spatial variability of the major chemistry of the Antarctic ice sheet. Ann. Glaciol., 20, 440-447.

Perovich, D.K. and J.A. Richter-Menge. 1994. Surface characteristics of lead ice. J. Geophys. Res., 99(C8), 16,341-16,350.

Rankin, A.M. and E.W. Wolff. 2003. A year-long record of sizesegregated aerosol composition at Halley, Antarctica. J. Geophys. Res., 108(D24), 4775. (10.1029/2003JD003993.)

Rankin, A.M., V. Auld and E.W. Wolff. 2000. Frost flowers as a source of fractionated sea salt aerosol in the polar regions. Geophys. Res. Lett., 27(21), 3469-3472.

Rankin, A.M., E.W. Wolff and S. Martin. 2002. Frost flowers: implications for tropospheric chemistry and ice core interpretation. J. Geophys. Res., 107(D23), 4683. (10.1029/ 2002JD002492.)

Reusch, D.B., P.A. Mayewski, S.I. Whitlow, I.I. Pittalwala and M.S. Twickler. 1999. Spatial variability of climate and past atmospheric circulation patterns from central West Antarctic glaciochemistry. J. Geophys. Res., 104(D6), 5985-6001.

Richardson, C. 1976. Phase relationships in sea ice as a function of temperature. J. Glaciol., 17(77), 507-519.

Simmonds, I. and T.H. Jacka. 1995. Relationships between the interannual variability of Antarctic sea ice and the Southern Oscillation. J. Climate, 8(3), 637-647.

Souney, J.M. and 7 others. 2002. A 700-year record of atmospheric circulation developed from the Law Dome ice core, East Antarctica. J. Geophys. Res., 107(D22), 4608-4616. (10.1029/ 2002JD002104.)

Wagenbach, D. and 7 others. 1998. Sea-salt aerosol in coastal Antarctic regions. J. Geophys. Res., 103(D9), 10,961-10,974.

Wettlaufer, J.S. and M.G. Worster. 1995. Dynamics of premelted films: frost heave in a capillary. Phys. Rev. E, 51(5-B), 46794689.

Whitlow, S., P.A. Mayewski and J.E. Dibb. 1992. A comparison of major chemical species seasonal concentration and accumulation at the South Pole and Summit, Greenland. Atmos. Environ., 26A(11), 2045-2054. 